\title{
Effect of hypobaric hypoxia on blood gases in patients with restrictive lung disease
}

\author{
C.C. Christensen*,\#, , M.S. Ryg" ${ }^{\#,}$, O. Kåre Refvem ${ }^{\uparrow}$, O. Henning Skjønsberg*
}

Effect of hypobaric hypoxia on blood gases in patients with restrictive lung disease. C.C. Christensen, M.S. Ryg, O. Kåre Refvem, O. Henning Skjønsberg. (C)ERS Journals Ltd 2002.

ABSTRACT: Several publications have reported effects of hypobaric conditions in patients with chronic obstructive pulmonary disease. To the current authors' knowledge, similar studies concerning patients with restrictive lung disease have not been published.

The effect of simulated air travel in a hypobaric chamber on arterial blood gases, blood pressure, and cardiac frequency during rest and $20 \mathrm{~W}$ exercise, and the response to supplementary oxygen in 17 patients with chronic restrictive ventilatory impairment has been investigated.

Resting oxygen tension in arterial blood $\left(P \mathrm{a}, \mathrm{O}_{2}\right)$ decreased from $10.4 \pm 1.6 \mathrm{kPa}$ at sea level to $6.5 \pm 1.1 \mathrm{kPa}$ at $2,438 \mathrm{~m}$ simulated altitude, and decreased further during light exercise in all patients $(5.1 \pm 0.9 \mathrm{kPa}) . P \mathrm{~Pa}, \mathrm{O}_{2}$ at this altitude correlated positively with sea-level $\mathrm{Pa}_{\mathrm{a}} \mathrm{O}_{2}$ and transfer factor of the lung for carbon monoxide $(T \mathrm{~L}, \mathrm{CO})$, and negatively with carbon dioxide tension in arterial blood $\left(\mathrm{Pa}, \mathrm{CO}_{2}\right), \mathrm{Pa}_{\mathrm{a}} \mathrm{O}_{2}$ increased to acceptable levels with an $\mathrm{O}_{2}$ supply of $2 \mathrm{~L} \cdot \mathrm{min}^{-1}$ at rest and $4 \mathrm{~L} \cdot \mathrm{min}^{-1}$ during $20 \mathrm{~W}$ exercise.

In conclusion, most of the patients with restrictive ventilatory impairment developed hypoxaemia below the recommended levels of in-flight oxygen tension in arterial blood during simulated air travel. Light exercise aggravated the hypoxaemia. Acceptable levels of oxygen tension in arterial blood, with only a minor increase in carbon dioxide tension in arterial blood, were obtained by supplementary oxygen.

Eur Respir J 2002; 20: 300-305.
*Dept of Pulmonary Medicine, Ullevål Hospital, Oslo, " Institute of Aviation Medicine, Blindern, Oslo and Glittreklinikken, Hakadal, Norway.

Correspondence: C.C. Christensen

Glittreklinikken

1488 Hakadal

Norway

Fax: 4767075344

E-mail: carl.christian.christensen@nih.no

Keywords: Air travel

cabin pressure altitude

commercial aircraft

hypoxia

oxygen

restrictive lung disease

Received: March 72001

Accepted after revision: December 12 2001
Federal aviation regulations specify rules for commercial aircraft of a maximal cabin altitude of $2,438 \mathrm{~m}$ ( $8,000 \mathrm{feet})$ in order to avoid hypoxaemia in crew and passengers $[1,2]$. The oxygen saturation $\left(\mathrm{Sa}, \mathrm{O}_{2}\right)$ in healthy subjects will exceed $90 \%$ at this cabin altitude and only a slight reduction in mental performance will be observed [3-5].

Passengers with chronic obstructive pulmonary disease (COPD) may experience a severe decrease in arterial blood oxygen content at a cabin altitude of $2,438 \mathrm{~m}[6,7]$. Three medical guidelines for COPD patients conclude that in-flight $\mathrm{O}_{2}$ supplementation should be considered if the $\mathrm{O}_{2}$ tension in arterial blood $\left(\mathrm{Pa}, \mathrm{O}_{2}\right)$ at $2,438 \mathrm{~m}$ altitude is $<6.7 \mathrm{kPa}(50 \mathrm{mmHg})[8$, 9] or $7.3 \mathrm{kPa}(55 \mathrm{mmHg})$ [10], respectively, since hypoxaemia below these levels is considered to be associated with increased risk of medical complications [11, 12]. Several studies concerning preflight evaluation of COPD patients have suggested screening criteria based on sea-level blood gases, spirometry, and exercise capacity $[8-10,13-16]$. However, to the current authors' knowledge, similar studies concerning hypobaric conditions on patients with restrictive ventilatory impairment have not previously been performed.

The present investigation was carried out to study the influence of low atmospheric pressure on arterial blood gases in patients with chronic restrictive ventilatory impairment. In addition, the authors wanted to evaluate the effect of supplementary $\mathrm{O}_{2}$ on arterial blood gases and cardiovascular function under these conditions, both at rest and during light exercise. The exercise tests were performed because it is recommended that passengers take brief walks during long distance flights to avoid thromboembolic complications. Seventeen patients with chronic restrictive ventilatory impairment were studied at rest and during bicycle exercise (at a rate equivalent to slow walking along the aisle of an airplane) at sea level and at $2,438 \mathrm{~m}$ simulated altitude in a hypobaric chamber.

\section{Methods}

Seventeen patients, 10 females and seven males, attending a rehabilitation programme were recruited for the study (group 1, table 1). They all suffered from chronic restrictive ventilatory impairment (total lung capacity (TLC) $<95 \%$ confidence interval) [17], caused by either sequelae from tuberculosis (five patients), kyphoscoliosis (two patients), or lung fibrosis (sarcoidosis: three patients; fibrosing alveolitis: two patients; 
Table 1.-Lung function and arterial blood gases in 17 patients with chronic restrictive ventilatory impairment (group 1)

\begin{tabular}{|c|c|c|c|}
\hline & Mean $\pm 1 \mathrm{SD}$ & Range & $\%$ pred \\
\hline Age yrs & $56.8 \pm 14.9$ & $26-74$ & \\
\hline Height $\mathrm{cm}$ & $170.5 \pm 11.7$ & $144-190$ & \\
\hline Weight kg & $72.2 \pm 14.0$ & $50-102$ & \\
\hline $\mathrm{Hgb}$ g \% & $14.0 \pm 4.1$ & $12.8-17.1$ & \\
\hline $\mathrm{BP}$ sys $\mathrm{mmHg}$ & $149.6 \pm 36.5$ & $105-266$ & \\
\hline BPdia $\mathrm{mmHg}$ & $81.7 \pm 18.3$ & $50-118$ & \\
\hline$f \mathrm{C} \min ^{-1}$ & $87.2 \pm 10.7$ & $68-105$ & \\
\hline VC L & $2.0 \pm 0.7$ & $1.0-3.6$ & $54 \pm 16$ \\
\hline FEV1 L & $1.4 \pm 0.6$ & $0.7-2.8$ & $49 \pm 18$ \\
\hline TLC L & $3.2 \pm 1.0$ & $1.7-4.7$ & $52 \pm 11$ \\
\hline $\begin{array}{l}T \mathrm{~L}, \mathrm{CO} \\
\mathrm{mmol} \cdot \mathrm{min}^{-1} \cdot \mathrm{kPa}^{-1}\end{array}$ & $4.8 \pm 1.4$ & $2.6-7.4$ & $54 \pm 18$ \\
\hline$P \mathrm{a}, \mathrm{O}_{2} \mathrm{kPa}$ & $10.4 \pm 1.6$ & $6.6-13.0$ & \\
\hline $\mathrm{Sa}, \mathrm{O}_{2} \%$ & $95.0 \pm 2.2$ & 87.9-97.7 & \\
\hline$P \mathrm{a}, \mathrm{CO}_{2} \mathrm{kPa}$ & $5.2 \pm 0.7$ & $4.1-6.4$ & \\
\hline $\begin{array}{l}\text { Aerobic capacity } \\
\mathrm{mL} \cdot \mathrm{min}^{-1} \cdot \mathrm{kg}^{-1}\end{array}$ & $13.8 \pm 3.7$ & $8.6-22.8$ & $44 \pm 11$ \\
\hline
\end{tabular}

$\mathrm{Hgb}$ : haemoglobin concentration; BPsys: systolic blood pressure at rest, sea level; BPdia: diastolic blood pressure at rest, sea level; $f_{C}$ : cardiac frequency; $\mathrm{VC}$ : vital capacity; FEV1: forced expiratory volume in one second; TLC: total lung capacity; TL,CO: single-breath transfer factor of the lung for carbon monoxide; $\mathrm{Pa}_{\mathrm{a}} \mathrm{O}_{2}$ : oxygen tension in arterial blood; $S_{\mathrm{a}, \mathrm{O}_{2}}$ : arterial oxygen saturation; $P_{\mathrm{a}, \mathrm{CO}_{2}}$ : carbon dioxide tension in arterial blood; aerobic capacity: oxygen consumption divided by body weight.

unspecified lung fibrosis: five patients). At the time of testing, all were in a stable phase of their disease. Two patients with mild hypertension received amlodipine $\left(2.5 \mathrm{mg} \cdot \mathrm{day}^{-1}\right)$ or spironolactone $\left(50 \mathrm{mg} \cdot \mathrm{day}^{-1}\right)$, and seven used oral or inhaled corticosteroids. Two had a history of myocardial infarction, without ventricular dysfunction. Patients with coexisting medical problems that might influence their physical capacity were excluded from the study. However, because analysis of blood pressures was performed after completion of the experiments, the authors failed to observe that one of the patients had a resting diastolic pressure of $118 \mathrm{mmHg}$ on the day of the experiment. To test an equation for the prediction of in-flight $\mathrm{Pa}, \mathrm{O}_{2}$ from preflight variables in these 17 patients, a separate group, consisting of 11 patients with chronic restrictive ventilatory impairment, was studied (group 2, table 2). The Regional Medical Ethics Committee approved the study, and written informed consent was obtained from all participants.

Vital capacity (VC), forced expiratory volume in one second (FEV1), TLC, single-breath transfer factor of the lung for carbon monoxide $(T \mathrm{~L}, \mathrm{CO})[18]$, and aerobic capacity were measured before the altitude experiment, as previously reported [7].

The experiments were performed with one patient and three technicians present in an air-conditioned $\left(3 \mathrm{~m}^{3} \cdot \mathrm{min}^{-1}, 25^{\circ} \mathrm{C}\right)$ hypobaric altitude chamber $\left(20 \mathrm{~m}^{3}\right)$ with stable concentrations of $\mathrm{O}_{2}$ and carbon dioxide. In group 1 , the subjects sat in a chair to use a cycle ergometer. After $\geqslant 10 \mathrm{~min}$ rest, they started cycling at $20 \mathrm{~W}$, increasing by $10 \mathrm{~W}$ every $4 \mathrm{~min}$, but here only responses during rest and $20 \mathrm{~W}$ exercise are
Table 2. - Lung function and arterial blood gases at rest at sea level in 11 patients with chronic restrictive ventilatory impairment (group 2)

\begin{tabular}{|c|c|c|c|}
\hline & Mean $\pm 1 \mathrm{SD}$ & Range & $\%$ pred \\
\hline Age yrs & $57.5 \pm 9.0$ & $42-71$ & \\
\hline Height $\mathrm{cm}$ & $167.6 \pm 11.7$ & $153-187$ & \\
\hline Weight $\mathrm{kg}$ & $76.2 \pm 20.4$ & $47-111$ & \\
\hline $\mathrm{VC} \mathrm{L}$ & $2.4 \pm 0.9$ & $1.1-4.3$ & $69 \pm 21$ \\
\hline FEV1 L & $1.8 \pm 0.7$ & $0.9-3.44$ & $63 \pm 26$ \\
\hline TLC L & $3.9 \pm 0.9$ & $3.0-5.7$ & $68 \pm 14$ \\
\hline $\begin{array}{l}T \mathrm{~L}, \mathrm{CO} \\
\quad \mathrm{mmol} \cdot \mathrm{min}^{-1} \cdot \mathrm{kPa}^{-1}\end{array}$ & $4.7 \pm 2.5$ & $1.3-9.7$ & $53 \pm 20$ \\
\hline$P a, O_{2} \mathrm{kPa}$ & $10.3 \pm 2.0$ & $6.2-12.6$ & \\
\hline $\mathrm{Sa}, \mathrm{O}_{2} \%$ & $95.3 \pm 4.6$ & $82.3-98.3$ & \\
\hline$P \mathrm{a}, \mathrm{CO}_{2} \mathrm{kPa}$ & $5.1 \pm 0.8$ & $4.1-7.0$ & \\
\hline $\begin{array}{l}\text { Aerobic capacity } \\
\mathrm{mL} \cdot \mathrm{min}^{-1} \cdot \mathrm{kg}^{-1}\end{array}$ & $19.9 \pm 5.8$ & $13.4-30.1$ & $66 \pm 15$ \\
\hline
\end{tabular}

VC: vital capacity; FEV1: forced expiratory volume in one second; TLC: total lung capacity; TL,CO: single-breath transfer factor of the lung for carbon monoxide; $P \mathrm{a}, \mathrm{O}_{2}$ : oxygen tension in arterial blood; $\mathrm{Sa}_{2} \mathrm{O}_{2}$ : arterial oxygen saturation; $\mathrm{Pa}, \mathrm{CO}_{2}$ : carbon dioxide in arterial blood; aerobic capacity: oxygen consumption divided by body weight.

reported. The procedure was performed in a random order at sea level and a simulated altitude of $2,438 \mathrm{~m}$ $(8,000 \mathrm{ft})$, with $60 \mathrm{~min}$ rest between each exercise test. In group 2, the subjects were only exposed to hypobaric hypoxia $(2,438 \mathrm{~m})$ without exercise. Arterial blood samples were drawn every 4 min from a catheter in the radial artery. The samples were stored on melting ice in sealed syringes for $10-15 \mathrm{~min}$ before being sluiced out of the chamber and analysed for blood gases [7]. The heart rhythm was continuously monitored, and arterial blood pressure was recorded through the catheter in the radial artery using a Mingograf 7 (Siemens-Elema, Solna, Sweden) and a Baxter TruWave disposable pressure transducer (Glendale, CA, USA).

After terminating the measurements at sea level and $2,438 \mathrm{~m}$, the patients in group 1 were tested at $2,438 \mathrm{~m}$ at rest and during $20 \mathrm{~W}$ exercise with and without a supply of $100 \% \mathrm{O}_{2}$ through a double nasal cannula. The $\mathrm{O}_{2}$ flow rates of 1,2 and $4 \mathrm{~L} \cdot \mathrm{min}^{-1}$ were blinded for the patients. Arterial blood gases, intraarterial blood pressure and cardiac frequency were measured at 4 min intervals. Two of the subjects did not participate in the study of supplementary $\mathrm{O}_{2}$, because they feared increased dyspnoea during a repeated exercise test.

Results are expressed as mean \pm SD. All variables, except $\mathrm{Sa}_{\mathrm{a}} \mathrm{O}_{2}$, were normally distributed, and as a result, paired t-tests were used to evaluate differences between sea level and altitude. A Mann-Whitney test was used for $\mathrm{Sa}_{\mathrm{a}} \mathrm{O}_{2}$. To test for combined effects, linear regression analysis of $\mathrm{Pa}_{\mathrm{a}} \mathrm{O}_{2}(2,438 \mathrm{~m})$ versus $P \mathrm{a}, \mathrm{O}_{2}$ (sea level), TL,CO (\% of predicted [8]), and $\mathrm{Pa}_{1} \mathrm{CO}_{2}$ (sea level) was performed, because of the significant bivariate correlations between the first and the latter three variables. The effect of $\mathrm{O}_{2}$ supply was tested using a two factor (rest versus exercise, and level of $\mathrm{O}_{2}$ supply) repeated measures analysis of variance (ANOVA), followed by contrasts 
between different flow rates. Two-tailed p-values $<0.05$ were considered statistically significant.

\section{Results}

All subjects had a TLC $<80 \%$ pred, as shown in table 1 . Values for VC, FEV1 and TL,CO were also reduced to $\sim 50 \%$ pred. All except one of the subjects were nonsmokers.

Individual values for arterial blood gases are presented in figure $1(\mathrm{a}-\mathrm{c})$. There was a considerable decrease in $\mathrm{Pa}, \mathrm{O}_{2}$ and $\mathrm{Sa}, \mathrm{O}_{2}$ as the patients were taken from sea level to $2,438 \mathrm{~m}$ altitude (table 3). During $20 \mathrm{~W}$ exercise, $\mathrm{Pa}, \mathrm{O}_{2}$ and $\mathrm{Sa}, \mathrm{O}_{2}$ decreased markedly as compared to resting values, both at sea level and at $2,438 \mathrm{~m}$ (table 3 ). All subjects managed the work load $(20 \mathrm{~W})$ at sea level for $\geqslant 4 \mathrm{~min}$, but at $2,438 \mathrm{~m}$ three subjects terminated after 2 min because of dyspnoea. In the figures showing $20 \mathrm{~W}$ exercise, blood values from these subjects are also included.

There was a statistically significant decrease in resting $\mathrm{Pa}, \mathrm{CO}_{2}$ from sea level to $2,438 \mathrm{~m}$ (table 3 ). During $20 \mathrm{~W}$ exercise, $P \mathrm{a}, \mathrm{CO}_{2}$ increased significantly at sea level, but not at altitude. Resting ventilation was not significantly different at sea level and at 2,438 m. During $20 \mathrm{~W}$ exercise, however, the ventilation at $2,438 \mathrm{~m}$ was significantly higher than at sea level (table 3 ).

The resting $P$ a, $\mathrm{O}_{2}$ at $2,438 \mathrm{~m}$ was correlated to both the sea-level $\mathrm{Pa}_{\mathrm{a}} \mathrm{O}_{2}(\mathrm{r}=0.73, \mathrm{p}<0.001), T \mathrm{~L}, \mathrm{CO}(\mathrm{r}=0.59$, $\mathrm{p}<0.02)$ and $T \mathrm{~L}, \mathrm{CO}$ in per cent of predicted values $(\mathrm{r}=0.69, \mathrm{p}<0.01)$, and negatively correlated to $\mathrm{Pa}, \mathrm{CO}_{2}$ $(\mathrm{r}=-0.55, \mathrm{p}<0.05)$. There was no significant correlation between in-flight $P \mathrm{a}, \mathrm{O}_{2}$ and sea-level values of $\mathrm{VC}$, FEV1, TLC, or aerobic capacity.

A multiple linear regression analysis of $\mathrm{Pa}, \mathrm{O}_{2}$ (in $\mathrm{kPa})$ at $2,438 \mathrm{~m}$ versus $\mathrm{T} \mathrm{L}, \mathrm{CO}$ and $\mathrm{Pa}_{\mathrm{a}} \mathrm{O}_{2}$ at sea level gave the following equation:

$$
\begin{aligned}
P_{\mathrm{a}, \mathrm{O}_{2}}(2,438 \mathrm{~m})= & 0.74+0.39 \times P_{\mathrm{a}, \mathrm{O}_{2}}(\text { sea level }) \\
& +0.033 \times T \mathrm{~L}, \mathrm{CO}(\% \text { pred })
\end{aligned}
$$

with multiple $\mathrm{r}=0.88$. The deviations from predicted $P \mathrm{a}, \mathrm{O}_{2}$ ranged from an overestimate of $1.0 \mathrm{kPa}$ to an underestimate of $0.7 \mathrm{kPa}$ and were normally distributed. Sea-level $\mathrm{Pa}_{1} \mathrm{CO}_{2}$ had no significant relation to $P a, \mathrm{O}_{2}$ at altitude in the multiple regression. In group 2, no significant difference between measured in-flight $P \mathrm{a}, \mathrm{O}_{2}$ and $\mathrm{Pa}, \mathrm{O}_{2}$ pred from the equation above $(0.25 \pm 0.46 \mathrm{kPa}$, range $-0.43-0.81 \mathrm{kPa})$ was observed.
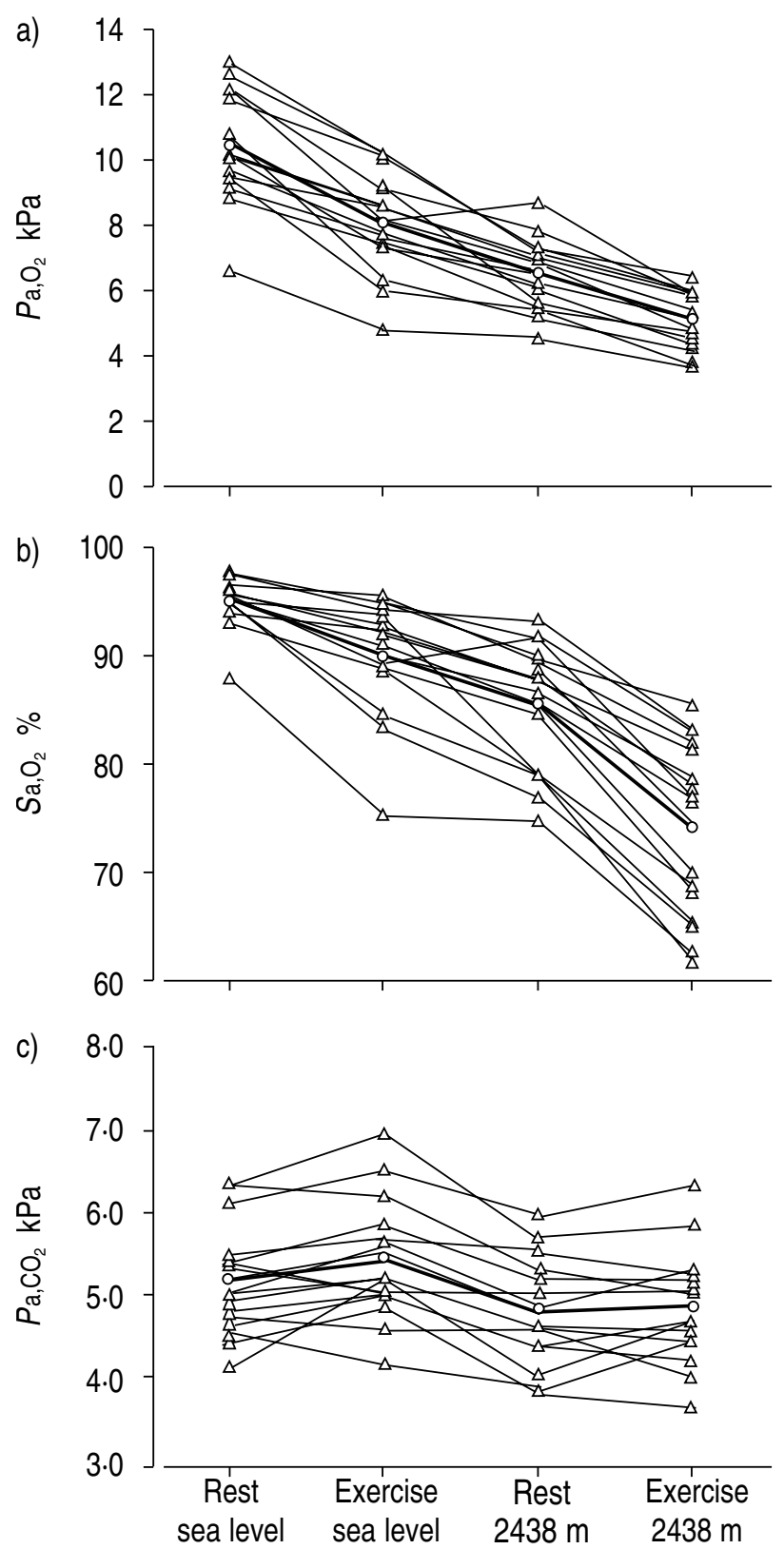

Fig. 1.-Arterial blood gas values from 17 patients with chronic restrictive ventilatory impairment during rest and $20 \mathrm{~W}$ ergometer cycle exercise at sea level and at $2,438 \mathrm{~m}$ (8,000 feet) altitude. Individual $(\triangle)$ and mean values $(\bigcirc)$ of a) oxygen tension in arterial blood $\left(\mathrm{Pa}_{\mathrm{a}} \mathrm{O}_{2}\right)$, b) arterial oxygen saturation $\left(\mathrm{Sa}_{\mathrm{a}} \mathrm{O}_{2}\right)$ and c) carbon dioxide tension in arterial blood $\left(\mathrm{Pa}_{\mathrm{a}, \mathrm{CO}_{2}}\right)$.

Table 3. - Blood gases and ventilation at rest and during $20 \mathrm{~W}$ exercise at sea level and 2,438 m simulated altitude (group

\begin{tabular}{|c|c|c|c|c|}
\hline & \multicolumn{2}{|c|}{ Sea level } & \multicolumn{2}{|c|}{$2,438 \mathrm{~m}$} \\
\hline & Rest & Exercise & Rest & Exercise \\
\hline $\begin{array}{l}P \mathrm{a}, \mathrm{O}_{2} \mathrm{kPa} \\
\mathrm{Sa}, \mathrm{O}_{2} \% \\
\mathrm{~Pa}, \mathrm{CO}_{2} \mathrm{kPa} \\
\text { Ventilation } \mathrm{L} \cdot \mathrm{min}^{-1}\end{array}$ & $\begin{array}{r}10.4 \pm 1.6 \\
95.0 \pm 2.2 \\
5.2 \pm 0.7 \\
11.3 \pm 3.4\end{array}$ & $\begin{array}{l}8.1 \pm 1.5 * * * \\
90.1 \pm 5.1 * * * \\
5.4 \pm 0.7 * * \\
23.7 \pm 7.5\end{array}$ & $\begin{array}{c}6.5 \pm 1.1^{\# \# \#} \\
85.4 \pm 5.6^{\# \# \#} \\
4.8 \pm 0.6^{\# \# \#} \\
12.1 \pm 4.5\end{array}$ & $\begin{array}{c}5.1 \pm 0.9 * * * \\
74.2 \pm 7.8^{* * * *} \\
4.9 \pm 0.7 \\
27.2 \pm 8.1\end{array}$ \\
\hline
\end{tabular}
1)

$P \mathrm{a}, \mathrm{O}_{2}$ : oxygen tension in arterial blood; $\mathrm{Sa}_{\mathrm{a}} \mathrm{O}_{2}$ : arterial oxygen saturation; $\mathrm{Pa}_{\mathrm{a}} \mathrm{CO}_{2}$ : carbon dioxide tension in arterial blood.

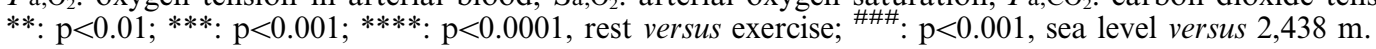


a)

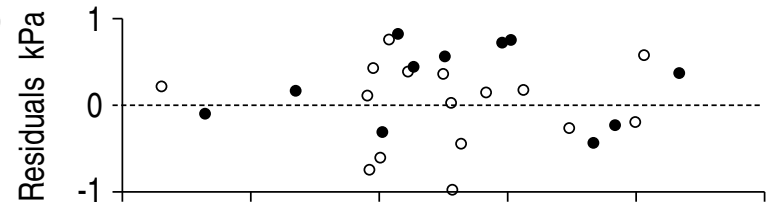

b)

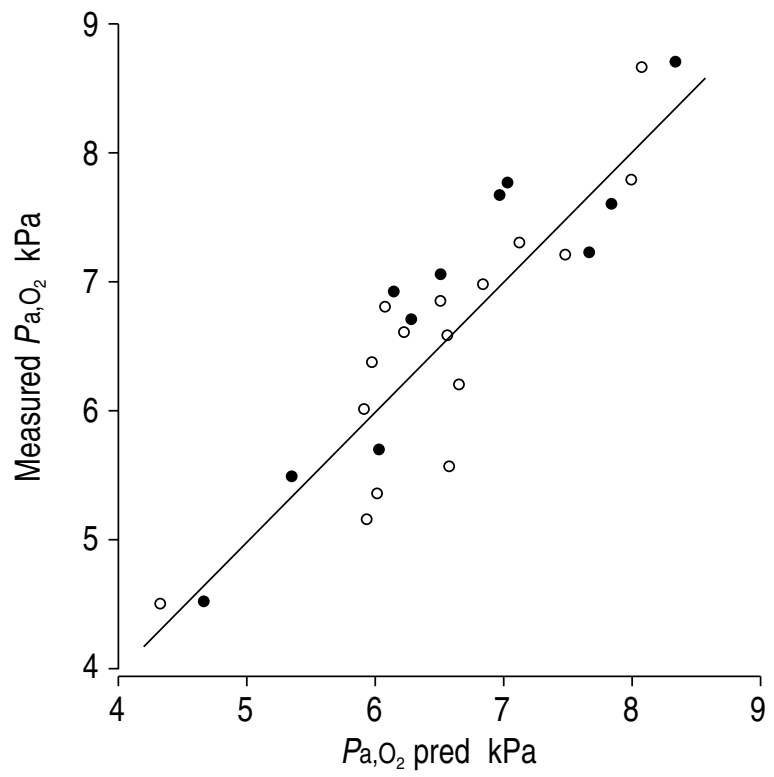

Fig. 2.-Comparison of measured in-flight oxygen pressure in arterial blood $\left(\mathrm{Pa}_{\mathrm{a}} \mathrm{O}_{2}\right)$ and $\mathrm{Pa}_{\mathrm{a}} \mathrm{O}_{2}$ pred from the equation $\mathrm{Pa}_{\mathrm{a}} \mathrm{O}_{2}$ $(2,438 \mathrm{~m})=0.74+0.39 \times P \mathrm{a}, \mathrm{O}_{2}$ (sea level) $+0.033 \times$ transfer factor of the lung for carbon monoxide (\% pred). $\bigcirc$ : group 1; $\bullet$ : group 2.

A comparison of measured and predicted $\mathrm{Pa}, \mathrm{O}_{2}$ values at $2,438 \mathrm{~m}$ is shown in figure 2 .

By giving resting patients supplementary $\mathrm{O}_{2}$ $\left(1 \mathrm{~L} \cdot \mathrm{min}^{-1}\right)$ at $2,438 \mathrm{~m}$, there was a statistically significant increase in $\mathrm{Pa}, \mathrm{O}_{2}$ at rest and during exercise (fig. 3a). Further increases were observed at flow rates of 2 and $4 \mathrm{~L} \cdot \mathrm{min}^{-1}$. Likewise, $\mathrm{Sa}_{\mathrm{a}} \mathrm{O}_{2}$ increased with increasing rates of $\mathrm{O}_{2}$ supply (fig. 3b). At rest and during exercise, $\mathrm{Sa}_{\mathrm{a}} \mathrm{O}_{2}$ increased markedly when the $\mathrm{O}_{2}$ supply increased from 0 to $1 \mathrm{~L} \cdot \mathrm{min}^{-1}$, and increased further with $2 \mathrm{~L} \cdot \mathrm{min}^{-1}$. At a flow rate of $4 \mathrm{~L} \cdot \mathrm{min}^{-1}$, $\mathrm{Sa}_{\mathrm{a}} \mathrm{O}_{2}$ increased relative to $2 \mathrm{~L} \cdot \mathrm{min}^{-1}$ during exercise, but not at rest. At rest, supplementary $\mathrm{O}_{2}$ resulted in a small but significant increase in $\mathrm{Pa}_{2} \mathrm{CO}_{2}$ at flow rates of 1 and $2 \mathrm{~L} \cdot \mathrm{min}^{-1}$, but no further increase at $4 \mathrm{~L} \cdot \mathrm{min}^{-1}$ (fig. 3c). During $20 \mathrm{~W}$ exercise, there was no increase in $P$ a, $\mathrm{CO}_{2}$ from 0 to $1 \mathrm{~L} \cdot \mathrm{min}^{-1}$, but a minor increase with $4 \mathrm{~L} \cdot \mathrm{min}^{-1}$ (fig. $3 \mathrm{c}$ ).

$\mathrm{O}_{2}$ supply at $2,438 \mathrm{~m}$ caused a decrease of $\sim 9 \%$ in systolic blood pressure during $20 \mathrm{~W}$ exercise, but did not cause significant changes in blood pressure at rest (fig. 3d). Diastolic blood pressure was not affected by $\mathrm{O}_{2}$ supply. Resting cardiac frequency was reduced with an $\mathrm{O}_{2}$ supply of $2 \mathrm{~L} \cdot \mathrm{min}^{-1}$. During $20 \mathrm{~W}$ exercise the heart rate decreased $\sim 8 \%$ with an $\mathrm{O}_{2}$ supply of $4 \mathrm{~L} \cdot \mathrm{min}^{-1}$ (fig. 3e).

\section{Discussion}

Patients with various diseases leading to chronic restrictive ventilatory impairment developed pronounced
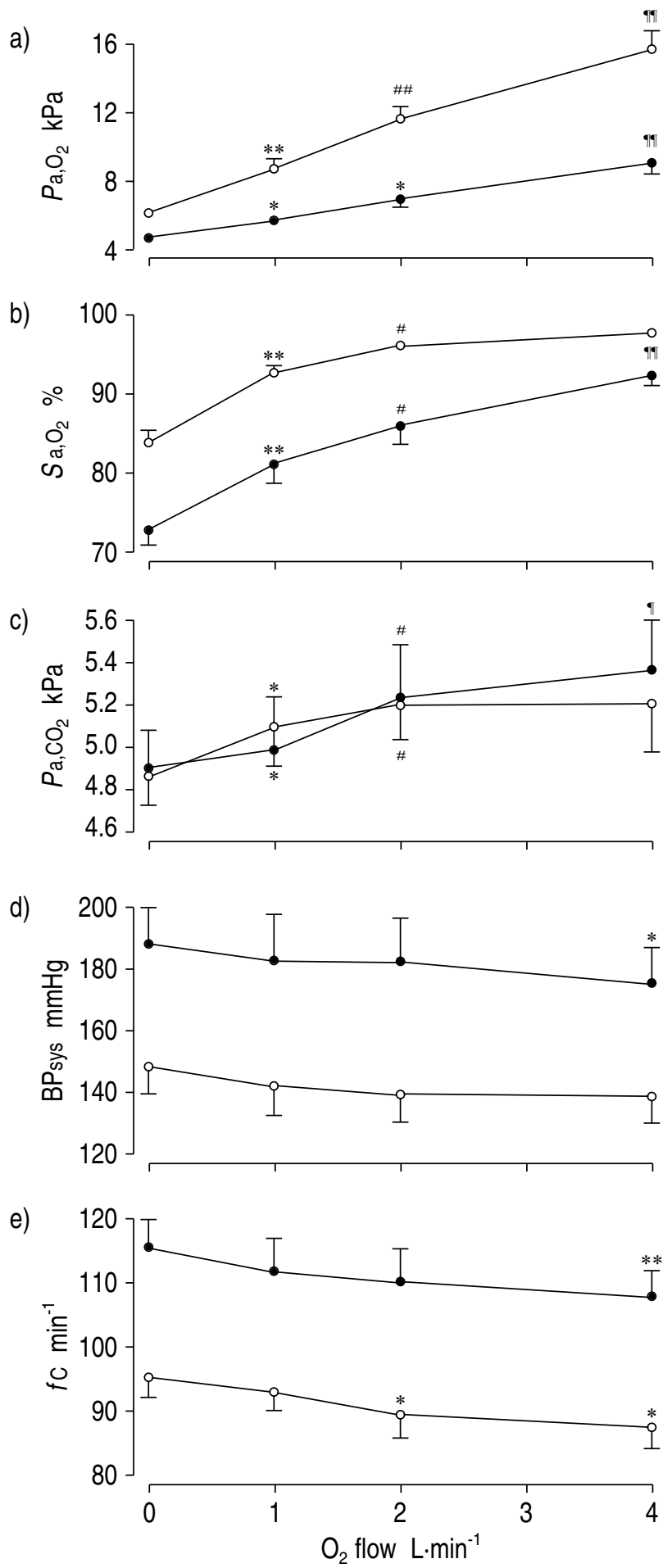

Fig. 3. - Effect of supplementary oxygen $\left(\mathrm{O}_{2}\right)$ (mean \pm SEM) in 15 patients with chronic restrictive impairment at $2,438 \mathrm{~m}(8,000$ feet) simulated cabin altitude at rest $(\bigcirc)$ and during $20 \mathrm{~W}$ ergometer cycle exercise ( $(\bullet)$ a) Oxygen tension in arterial blood $\left(P_{\mathrm{a}}, \mathrm{O}_{2}\right)$, b) arterial oxygen saturation $\left(\mathrm{Sa}_{\mathrm{a}} \mathrm{O}_{2}\right)$, c) carbon dioxide tension in arterial blood $\left(P_{\mathrm{a}}, \mathrm{CO}_{2}\right)$, d) systolic blood pressure $\left(\mathrm{BP}_{\text {sys }}\right)$ and e) cardiac frequency $(f \mathrm{C}) . *{ }^{*}: \mathrm{p}<0.05 ; * *: \mathrm{p}<0.01$ compared to values without supplementary oxygen; ${ }^{\#}$ : $\mathrm{p}<0.05$; ${ }^{\# \#}$ : $\mathrm{p}<0.01$ compared to values with supplementary oxygen at flow rate $1 \mathrm{~L} \cdot \mathrm{min}^{-1} ;$; $\mathrm{p}<0.05 ;{ }^{\top}: \mathrm{p}<0.01$ compared to values with supplementary oxygen at flow rate $2 \mathrm{~L} \cdot \mathrm{min}^{-1}$. 
hypoxaemia during simulated air travel at a cabin altitude of $2,438 \mathrm{~m}$. The hypoxaemia was aggravated by light exercise, equivalent to slow walking along the aisle. The number of subjects was too small to evaluate each group of patients separately, but taken as a whole they seemed to respond to hypoxia in a similar manner. The spirometry and blood gas values showed an equal distribution among the different diagnoses, with a mean reduction in lung function parameters of $\sim 50 \%$ pred. All patients included in the study were physically capable of travelling, and were thus potential aircraft passengers.

Guidelines for preflight medical evaluation are available for COPD patients [8-10], but not for other categories of lung patients. The intention of preflight medical evaluation is to avoid severe hypoxaemia provoked by the lowered cabin pressure in the aircraft. The lower limits for in-flight $\mathrm{Pa}_{\mathrm{a}} \mathrm{O}_{2}(2,438 \mathrm{~m})$, recommended in medical guidelines for COPD patients, are $7.3 \mathrm{kPa}[10]$ and $6.7 \mathrm{kPa}[8,9]$, respectively, but it is not evident how these values have been established $[11,12]$. To the present authors' knowledge, studies on patients with restrictive ventilatory impairment at high altitude have not been published. According to the results presented here, these patients run a high risk of developing in-flight hypoxaemia, below the recommended levels. It was found that $82 \%$ expressed in-flight $\mathrm{Pa}, \mathrm{O}_{2}$ values $<7.3 \mathrm{kPa}$ and $53 \%<6.7 \mathrm{kPa}$ at rest. Even patients with $\mathrm{Pa}, \mathrm{O}_{2}$ values close to normal at sea level, experienced a pronounced drop in $\mathrm{Pa}, \mathrm{O}_{2}$ in the altitude chamber.

Effects of exercise at altitude have received little attention in the medical guidelines. However, passengers are recommended to take light exercise during longer flights to avoid thromboembolic complications [19]. In this study, light exercise at sea level resulted in a reduced $\mathrm{Pa}, \mathrm{O}_{2}$ compared to the resting situation, but none of the patients became severely hypoxaemic. However, the same level of exercise at $2,438 \mathrm{~m}$ resulted in a $P \mathrm{a}, \mathrm{O}_{2}$ level $<6.7 \mathrm{kPa}$ in all subjects, with a mean value of $5.1 \mathrm{kPa}$. In one patient with $P \mathrm{a}, \mathrm{O}_{2} 9.4 \mathrm{kPa}$ (sea level) at rest, the exercise $\mathrm{Pa}, \mathrm{O}_{2}$ $(2,438 \mathrm{~m})$ was as low as $3.7 \mathrm{kPa}$.

Medical guidelines for COPD patients [8-10] recommend sea-level $\mathrm{Pa}_{\mathrm{a}} \mathrm{O}_{2}$ as a reliable predictor of $\mathrm{Pa}, \mathrm{O}_{2}$ at $2,438 \mathrm{~m}$. Based on a study performed by the current authors on COPD patients in an altitude chamber, this recommendation could not be supported [7]. In the present study, there was a significant correlation between $\mathrm{Pa}_{\mathrm{a}} \mathrm{O}_{2}$ at sea level and $\mathrm{Pa}, \mathrm{O}_{2}$ at $2,438 \mathrm{~m}$, but only $53 \%$ of the variance of in-flight $P$ a, $\mathrm{O}_{2}$ could be accounted for by differences in sea-level $P \mathrm{a}, \mathrm{O}_{2}$. The prediction of $P \mathrm{a}, \mathrm{O}_{2}$ at $2,438 \mathrm{~m}$ could be improved by including $T \mathrm{~L}, \mathrm{CO}(\%$ pred) in the regression, but in this study, sea-level $\mathrm{Pa}_{2} \mathrm{O}_{2}$ and $T \mathrm{~L}, \mathrm{CO}$ accounted for only $77 \%$ of the variance in $P \mathrm{a}, \mathrm{O}_{2}$ at $2,438 \mathrm{~m}$. Even though the patients in group 2 showed no significant difference between measured in-flight $P \mathrm{a}, \mathrm{O}_{2}$ and $\mathrm{Pa}, \mathrm{O}_{2}$ predicted from this regression, there is still a possibility of overestimating the in-flight $\mathrm{Pa}, \mathrm{O}_{2}$ by using pre-flight parameters for prediction. Therefore, patients who might be particularly vulnerable to hypoxaemia should have priority to the limited resources of pre-flight evaluation under hypoxic conditions, either in a hypobaric chamber or testing by breathing a hypoxic gas mixture, as in the hypoxic altitude simulation test (HAST) [6]. The current authors used a hypobaric chamber in the present investigation because it was easily accessibly. However, breathing a hypoxic gas at sea-level pressure gives similar results [20]. Preflight evaluation might be offered to patients with accompanying heart disease and probably patients with hypercapnia, considering the observed negative correlation between pre-flight $\mathrm{Pa}, \mathrm{CO}_{2}$ and inflight $P$ a, $\mathrm{O}_{2}$. Hypercapnic patients might be less capable of increasing their ventilation in response to hypoxaemia. Conversely, preflight evaluation is controversial, and NAEIJE [21] recently pointed out that the benefit of such testing had never been documented.

At a cabin altitude of $2,438 \mathrm{~m}$, an $\mathrm{O}_{2}$ supply of $2 \mathrm{~L} \cdot \mathrm{min}^{-1}$ on a nasal cannula increased the $P \mathrm{a}, \mathrm{O}_{2}$ $(>8 \mathrm{kPa})$ and $\mathrm{Sa}_{2} \mathrm{O}_{2}(>92 \%)$ to acceptable levels in all subjects at rest, without causing alarmingly high levels of $\mathrm{Pa}_{\mathrm{a}} \mathrm{CO}_{2}$ (range $4.2-6.8 \mathrm{kPa}$ ). There was a minor decrease in resting cardiac frequency and systolic blood pressure. During $20 \mathrm{~W}$ exercise at $2,438 \mathrm{~m}$, equivalent to slow walking along the aisle, an $\mathrm{O}_{2}$ supply at $4 \mathrm{~L} \cdot \mathrm{min}^{-1}$ was sufficient to maintain $\mathrm{Pa}, \mathrm{O}_{2}$ $>7.3 \mathrm{kPa}$ and $\mathrm{Sa}, \mathrm{O}_{2}>88 \%$ in all but two patients. There was a significant decrease in both cardiac frequency and systolic blood pressure at $20 \mathrm{~W}$ exercise, reflecting the improved oxygenation. There was only a minor increase in $\mathrm{Pa}_{2} \mathrm{CO}_{2}$ with this $\mathrm{O}_{2}$ flow (range 4.1-7.4 kPa).

The pronounced decrease in oxygen tension in arterial blood at altitude seems to contrast with the low level of medical emergencies among patients with pulmonary disease [21-23]. This low incidence cannot be explained by a liberal prescription of supplementary oxygen. In a study among consultant respiratory physicians in England [24], approximately half of those measuring blood gas levels did not recommend in-flight supplementary oxygen unless the preflight oxygen tension in arterial blood was $<8.0 \mathrm{kPa}$, and an additional $25 \%$ recommended that it should not be used unless the oxygen tension in arterial blood was $<7.3 \mathrm{kPa}$. According to the results presented in this study, both chronic obstructive pulmonary disease [7] and restrictive lung patients with such preflight oxygen tension in arterial blood values will experience a decrease in oxygen tension in arterial blood to levels far below what is recommended in present guidelines [8-10]. One reason could be that the cabin altitude during most flights is lower than at 2,438 $\mathrm{m}$ [25]. However, the low frequency of medical emergencies indicate that these levels of hypoxaemia are generally well tolerated, and raises the question of whether the limit of acceptable in-flight oxygen tension in arterial blood should be reconsidered in future guidelines.

\footnotetext{
Acknowledgements. The authors would like to the staff at the Institute of Aviation Medicine, Oslo, Norway, for helping with laboratory work and with controlling the hypobaric chamber during experiments.
} 


\section{References}

1. US Government Printing Office. Code of Federal Regulations. Title 14, Vol. 1, Part 25. 1527. Washington, DC, US Government Printing Office, 1999.

2. Harding RM, Mills JF. Problems of altitude I: Hypoxia and hyperventilation. BMJ 1983; 286: 1408-1410.

3. Kelman GR, Crow TJ. Impairment of mental performance at a simulated altitude of 8,000 feet. Aerospace Med 1969; 40: 981-982.

4. McFarland RA. Human factors in relation to the development of pressurized cabins. Aerospace Med 1971; 42: 1303-1318.

5. DeHart RL. Fundamentals of aerospace medicine. 2nd Edn. Washington Square, Lea Fabinger 600, 1996; pp. 96-97.

6. Gong H Jr, Tashkin DP, Simmons MS. Hypoxiaaltitude simulation test. Am Rev Respir Dis 1984; 135: 980-986.

7. Christensen CC, Ryg M, Refvem OK, Skjønsberg OH. Development of severe hypoxaemia in COPD patients at 2,438 m (8,000 ft) altitude. Eur Respir $J$ 2000; 15: 635-639.

8. Standards for the diagnosis and care of patients with chronic obstructive pulmonary disease. Am J Respir Crit Care Med 1995; 152: S112-S113.

9. Siafakas NM, Vermeire P, Pride NB, et al. Optimal assessment and management of chronic obstructive pulmonary disease (COPD): a consensus statement of the European Respiratory Society. Eur Respir J 1995; 8: $1398-1420$

10. Aerospace Medical Association, Air Transport Medicine Committee. Medical guidelines for air travel. Aviat Space Environ Med 1996; 67: B1-B16.

11. Mills JF, Harding RM. Fitness to travel by air. BMJ 1983; 286: 1269-1271.

12. AMA Commision on Emergency Medical Services.
Medical aspects of transportation aboard commercial aircraft. JAMA 1982; 247: 1007-1011.

13. Gong $\mathrm{H}$ Jr. Advising pulmonary patients about commercial air travel. J Resp Dis 1990; 11: 484499.

14. Gong H, Lee Mark JA, Cowan MN. Pre-flight medical screenings of patients. Analysis of health and flight characteristics. Chest 1993; 104: 788-794.

15. Schwartz JS, Bencowitz HZ, Moser KM. Air travel hypoxaemia with chronic obstructive pulmonary disease. Ann Intern Med 1984; 100: 473-477.

16. Vohra KP, Klocke RA. Detection and correction of hypoxaemia associated with air travel. Am Rev Respir Dis 1993; 148: 1215-1219.

17. American Thoracic Society. Lung function testing: selection of reference values and interpretative strategies. Am Rev Respir Dis 1991; 144: 1202-1218.

18. Quanjer PH. Standardized lung function testing. Bull Eur Physiopathol Respir 1983; 19: 39-44.

19. Mercer A, Brown JD. Venous thromboembolism associated with air travel: a report of 33 patients. Aviat Space Environ Med 1998; 69: 154-157.

20. Dillard TA, Moores LK, Bilello KL, Phillips YY. The preflight evaluation. A comparison of the hypoxia inhalation test with hypobaric exposure. Chest 1995; 107: 352-357.

21. Naeije R. Preflight medical screening of patients. Eur Respir J 2000; 16: 197-199.

22. Rayman RB. Passenger safety, health and comfort: a review. Aviat Space Environ Med 1997; 68: 432-440.

23. Speizer C, Rennie C, Breton H. Prevalence of in-flight medical emergencies on commercial airlines. Ann Emerg Med 1989; 18: 26-29.

24. Coker RK, Patridge MR. Assessing the risk of hypoxia in flight: the need for more rational guidelines. Eur Respir J 2000; 15: 128-130.

25. Cottrell JJ. Altitude exposures during aircraft flight. Flying higher. Chest 1988; 93: 81-84. 